\title{
Risk Factors for Mortality among HIV/AIDS Patients
}

\author{
Zaki Mita Kusumaadhi ${ }^{1 *}$, Nur Farhanah ${ }^{2}$, Muchlis Achsan Udji Sofro ${ }^{2}$ \\ ${ }^{1}$ Medical Faculty of Diponegoro University / Dr Kariadi General Hospital Semarang, Indonesia \\ ${ }^{2}$ Division of Tropical and Infectious Disease, Department of Internal Medicine, Medical Faculty of \\ Diponegoro University / Dr Kariadi General Hospital Semarang, Indonesia
}

CrossMa

\begin{abstract}
Keywords:
HIV

Morbidity

Mortality

Risk
\end{abstract}

*) Correspondence to:

dokterzaki@gmail.com

Article history:

Received 04-12-2020

Accepted 06 -02-2021

Availableonline10-03-2021

\begin{abstract}
Background: Morbidity and mortality of HIV/AIDS infections is still high and as a global health problem particularly in Low-Middle Income Countries (LMICs). Indonesia ranks third in Asia Pacific in increasing HIV infection. A Study on risk factors for mortality in HIV/AIDS patients in Dr. Kariadi General Hospital has never been conducted.

Objective: This study analyzed the risk factors for mortality among HIV/AIDS patients.

Methods: Case control study, data from medical records of inpatients and outpatients in Dr. Kariadi General Hospital from January 2015 to December 2017.

Results: Study subject: Two hundred and ten HIV/AIDS patients, were included; $105(56.75 \%)$ as cases and $105(9.65 \%)$ control patients. The significant risk factors for mortality were as follow: male $(p=0.030)$; age $\geq 45$ years $(p=0.035)$; noncompliance to treatment ( $p=0,000)$; WHO clinical stage III and IV $(p=0,000)$; coinfection of pulmonary tuberculosis $(p=0,000)$; CD4 cell count $<200$ cells $/ \mathrm{mm}^{3}(p$ $=0,000)$; eGFR $<60 \mathrm{~mL} /$ minute $/ 1.72 \mathrm{~m}^{2}(p=0.001)$ and Hemoglobin level $<10 \mathrm{~g} / \mathrm{dL}$ $(p=0.008)$. The non-significant risk factors for mortality were as follow: level of education $(p=0.650)$; Hepatitis B co-infection $(p=0.153)$ and Hepatitis C coinfection $(p=0.506)$. The most important risk factors for mortality in this study in were non-compliance to treatment $(p=0.003$; OR $=3.285)$ and CD4 count $<200$ cells $/ \mathrm{mm}^{3}$ ( $p=0.014$; OR $\left.=5.480\right)$.

Conclusion: In this study, the risk factors for mortality in HIV/AIDS patients were male; age $\geq 45$ years; non-compliance to treatment; WHO clinical stage III and IV; co-infection of pulmonary tuberculosis, CD4 count $<200$ cells $/ \mathrm{mm}^{3}$; eGFR $<60$ $\mathrm{mL} / \mathrm{minute} / 1.72 \mathrm{~m}^{2}$ and $\mathrm{Hb}$ level $<10 \mathrm{~g} / \mathrm{dL}$. The most important risk factors for mortality were non-compliance to treatment and CD4 count $<200$ cells $/ \mathrm{mm}^{3}$
\end{abstract}

DIMJ, 2021, 2(1), 20-29 DOI: https:// doi.org/10.14710/dimj.v2i1.9667

\section{Introduction}

Human Immunodeficiency Virus (HIV) is a major public health problem worldwide. The high incidence and mortality rate of HIV infection and Acquired Immune Deficiency Syndrome (AIDS) is a global health problem. World Health Organization (WHO) estimates that 36.7 million people worldwide are living with HIV / AIDS by the end of 2016.1 Indonesia is reported as one of the Asian countries that has experienced a significant increase in HIV infection with a number of new infection cases of 48,000 cases in 2016 and is ranked third in the Asia Pacific after India and China. The Data and Information Center of the Ministry of Health of the Republic of Indonesia in 2016 stated that until now HIV/AIDS has spread in 407 of 507 districts/cities $(80 \%)$ in all provinces in Indonesia. The cumulative number of HIV/AIDS cases in Indonesia from 1 April 1987 to 31 December 2016, namely HIV cases of 232,323 cases and AIDS 86,725 cases with a death toll of 14,608 cases. Central Java Province occupies the fifth position with the cumulative number of HIV cases of 14,690 cases and AIDS cases of $5,442 .^{2}$ The number of HIV/AIDS deaths in Central Java ranks third after DKI Jakarta and East Java Provinces, where from 1987 to March 2017 there were 1554 deaths with a Case Rate of $12.41 \% .^{3}$ HIV/AIDS has been one of the greatest challenges for decades. Determining the long-term mortality rate for HIV/AIDS cases is a challenge in itself. The prognosis of most untreated HIV/AIDS cases is poor with an overall mortality rate $>90 \%$ with a mean time between infection and death 8-10 years. ${ }^{4}$

Research on risk factors for mortality of HIV/AIDS patients in Indonesia is still rarely done 
and especially in Dr. Kariadi General Hospital has never been done. Sumantri R, et al in their research on important risk factors for mortality in HIV/AIDS patients at Dr. Hasan Sadikin General Hospital Bandung reported that CD4 count $\leq 50$ cells $/ \mathrm{mm}^{3}$, degree of moderate-severe anemia and Body Mass Index (BMI) <18.5 are important risk factors for mortality in HIV/AIDS patients. ${ }^{4}$

HIV infection will eventually cause a state of severe immunosuppression that causes the emergence of various AIDS clinical conditions and has a negative impact on the quality of life of patients and can even lead to death. However, the rate of progression of HIV disease among these patients was very broad. Identification of risk factors for progression of HIV infection to AIDS and even death is very important to recognize. This is an effort to carry out optimal management and management of HIV/AIDS patients so as to reduce the progression rate of HIV infection and the mortality rate for AIDS patients. $^{5}$

The decline in cases of death of HIV/AIDS patients in Indonesia has shown good progress and proves that the efforts of ARV treatment are effective, but research related to risk factors for mortality of HIV/AIDS patients is still rare. In an effort to plan and evaluate advance ARV therapy programs, it is important to know information on risk factors for mortality in HIV/AIDS patients. This is also one of the strategies to achieve the success of the AIDS program and as a step towards achieving the Getting to Zero which includes zero new infections, zero death from AIDS-related illness and zero discrimination which have become Indonesia's commitment in the 2007 ASEAN Declaration. ${ }^{6}$ This study tries to find the risk factors for mortality in HIV/AIDS patients in Dr. Kariadi General Hospital Semarang so that it will increase awareness of these risk factors for mortality in maintaining the quality of life of HIV/AIDS patients.

\section{Methods}

This research is a case control study. Retrieval of data from medical records of inpatients and outpatients at Dr. Kariadi General Hospital Semarang during the period January 2015 to December 2017. The study sample size was 210 HIV/AIDS patients consisting of 105 dead and 105 living patients.

The incoming data is processed manually for rechecking, coding, tabulation and entered into computer data entry for statistical analysis with the SPSS program. Univariate analysis was carried out to see data on data characteristics and to analyze the relationship between each independent variable and the dependent variable. The $p$ value is considered significant if $<0.05$. Bivariate analysis using the chisquare test with Yate correction at Alfa 0.05 which is equipped with a risk measure OR (Odd Ratio). Multivariate analysis used logistic regression analysis which involved all independent variables which had $p<0.05$ in bivariate analysis

\section{Results}

Four hundred and thirty-five inpatients and 837 new outpatients were including in this study (from January 2015 to December 2017). Based on these data, 113 inpatients died and 72 outpatients died. Sampling of 210 research subjects was carried out on inpatient and outpatient medical records which were considered quite complete, covering the 11 variables studied although not all of these medical records provided complete variables.

In this study, 136 people (64.8\%) was male and $72.4 \%$ died. Male is a risk factor for mortality in HIV/AIDS patients with a risk of death 1.966 times greater than that of women $(p=0.030$, OR 1.966). According to the age category, age $<45$ years and $\geq$ 45 years of study subjects were $160(76.2 \%)$ and 50 $(23.8 \%)$ respectively. Research subjects died in the age category $\geq 45$ years 32 people $(30.5 \%)$ and the age category $<45$ years 73 people $(69.5 \%)$. Age $\geq 45$ years is a significant risk factor for mortality in HIV/AIDS patients with a risk 2.119 times greater than those aged $<45$ years ( $p=0.035$, OR 2.119).

Research subjects based on the level of education are divided into the level of basic education (not in school, primary school, junior high school) 62 people $(29.5 \%)$ and advance education level (senior high school, college) 148 people $(70.5 \%)$. The number of research subjects died at the basic education level of 29 people (27.6\%) and the level of advance education 76 (72.4\%). Education level is not a risk factor for mortality in HIV/AIDS patients ( $p$ $=0.650$ ). Based on treatment compliance, the most research subjects died due to non-compliance to treatment of 59 people $(56.2 \%)$ and 46 people $(43.8 \%)$ were compliance to treatment. Noncompliance to treatment was a risk factor for mortality in HIV/AIDS patients and had a risk of 5.805 times greater than that of patients who were compliance to treatment ( $p=0.000$, OR 5.805) and in multivariate analysis was the most important risk factor for the mortality of HIV/AIDS patients $(p$ $=0.003$ )

The research subjects who died most were the WHO III and IV clinical stages as many as 105 people $(100 \%)$. WHO clinical stages III and IV are risk factors for mortality in HIV/AIDS patients $(p$ 
$=0.000$ ) but how much risk for stage III and IV patient mortality that occurs cannot be assessed because in data collection there were no patients with clinical stages I and II who died. Based on the presence or absence of pulmonary tuberculosis coinfection, research subjects died accompanied by pulmonary tuberculosis co-infection 48 people (45.7\%) while without pulmonary tuberculosis coinfection 57 people (54.3\%). Pulmonary tuberculosis co-infection is a risk factor for mortality in HIV/AIDS patients and a person with pulmonary tuberculosis co-infection has a 3.177 times greater risk of mortality than someone without pulmonary tuberculosis co-infection ( $p=0.000$, OR 3.177).

The study subjects who died based on the presence or absence of Hepatitis B co-infection were 54 people without Hepatitis B co-infection (51.42\%), 40 people $(38.11 \%)$ unknown status of Hepatitis B co-infection and 11 people with Hepatitis B coinfection. (10.47\%). Hepatitis B co-infection is not a risk factor for mortality in HIV/AIDS patients $(p$ $=0.153$ ). Based on the presence or absence of Hepatitis C co-infection, the majority of study subjects who died were unknown Hepatitis $\mathrm{C}$ coinfection status with 58 people $(55.24 \%)$, without Hepatitis C co-infection 42 people (40\%) and with Hepatitis C co-infection 5 people $(4.76 \%)$. Hepatitis $\mathrm{C}$ co-infection was not a risk factor for mortality in HIV/AIDS patients ( $p=0.506)$.

The CD4 count of the study subjects who died the most were with CD4 counts $<200$ cells $/ \mathrm{mm}^{3} 82$ people $(78.09 \%)$ while 4 people with CD4 counts $\geq$ 200 cells $/ \mathrm{mm}^{3}$ (3.8\%). The mean CD4 count of the study subjects died was 37.48 cells $/ \mathrm{mm}^{3}$. CD4 count
$<200$ cells $/ \mathrm{mm}^{3}$ is a risk factor for mortality in HIV/AIDS patients with a risk of 10.399 times greater than a CD4 count $\geq 200$ cells $/ \mathrm{mm}^{3}$ ( $p=0.000$, OR 10.399) and in multivariate analysis it is the most important risk factor for mortality in HIV/AIDS patients $(p=0.014)$. Based on eGFR, 62 people $(59 \%)$ of the study subjects died with eGFR $\geq 60$ $\mathrm{mL} /$ minute $/ 1.72 \mathrm{~m}^{2}$ and 43 people $(41 \%)$ died with eGFR $<60 \mathrm{~mL} /$ minute $/ 1.72 \mathrm{~m}^{2}$. The mean eGFR of the study subjects died was $71.19 \mathrm{~mL} /$ minute $/ 1.72$ $\mathrm{m}^{2}$. eGFR $<60 \mathrm{~mL} /$ minute $/ 1.72 \mathrm{~m}^{2}$ is a risk factor for mortality in HIV/AIDS patients with a risk of 3.139 times greater than eGFR $\geq 60 \mathrm{~mL} /$ minute $/ 1.72 \mathrm{~m}^{2}(p$ $=0.001$, OR 3.139). Based on Hb levels, 61 people $(58.1 \%)$ of the study subjects died at Hb levels $\geq 10$ $\mathrm{g} / \mathrm{dL}$ while 44 people $(41.9 \%)$ died at $\mathrm{Hb}$ levels $<10$ $\mathrm{g} / \mathrm{dL}$. The average $\mathrm{Hb}$ level of the study subjects died was $10.51 \mathrm{~g} / \mathrm{dL}$. Hb level $<10 \mathrm{~g} / \mathrm{dL}$ is a risk factor for mortality in HIV/AIDS patients and has a risk of 2.308 times greater than $\mathrm{Hb}$ level $\geq 10 \mathrm{~g} / \mathrm{dL}(p$ $=0.008$, OR 2.308).

The results of the chi-square test analysis showed that there were 8 variables which were significant as risk factors for the mortality of HIV/AIDS patients in Dr. Kariadi General Hospital Semarang, namely male, age $\geq 45$ years, treatment non-compliance, WHO III and IV clinical stages, pulmonary tuberculosis co-infection, CD4 count $<200$ cells $/ \mathrm{mm} 3$, eGFR $<60 \mathrm{~mL} /$ minute $/ 1.72 \mathrm{~m}^{2}$ and $\mathrm{Hb}<10 \mathrm{~g} / \mathrm{dL}$ while the level of education, hepatitis B co-infection and hepatitis $\mathrm{C}$ co-infection were not significant risk factors for the mortality of HIV/AIDS patients in Dr. Kariadi General Hospital Semarang as depicted in Table 1. 
Table 1. Characteristics Subjects of HIV/AIDS Patients

\begin{tabular}{|c|c|c|c|c|c|c|}
\hline Variable & $\begin{array}{l}\text { Died } \\
\text { n }(\%)\end{array}$ & $\begin{array}{l}\text { Lived } \\
\text { n }(\%)\end{array}$ & Median & Mean & OR & $p^{*}$ \\
\hline \multicolumn{7}{|c|}{ Demographic Characteristics } \\
\hline \multicolumn{7}{|c|}{ Sex } \\
\hline Male & $76(72.4 \%)$ & $60(57.1 \%)$ & & & 1.966 & 0.030 \\
\hline Female & $29(27.6 \%)$ & $45(42.9 \%)$ & & & & \\
\hline Age (year) & & & 35 & & & \\
\hline$<45$ & $73(69.5 \%)$ & $87(82.9 \%)$ & & & & \\
\hline$\geq 45$ & $32(30.5 \%)$ & $18(17.1 \%)$ & & & 2.119 & 0.035 \\
\hline \multicolumn{7}{|c|}{ Social Characteristics } \\
\hline \multicolumn{7}{|c|}{ Level of Education } \\
\hline Basic & $29(27.6 \%)$ & $33(31.4 \%)$ & & & 0.833 & 0.650 \\
\hline Advance & $76(72.4 \%)$ & $72(68.6 \%)$ & & & & \\
\hline \multicolumn{7}{|c|}{ Treatment Compliance } \\
\hline Yes & $46(43.8 \%)$ & $86(81.9 \%)$ & & & & \\
\hline No & $59(56.2 \%)$ & $19(18.1 \%)$ & & & 5.805 & 0.000 \\
\hline \multicolumn{7}{|c|}{ Clinical Characteristics } \\
\hline \multicolumn{7}{|c|}{ WHO Clinical Stage III and IV } \\
\hline Yes & $105(100 \%)$ & $56(53.3 \%)$ & & & - & 0.000 \\
\hline No & $0(0 \%)$ & $49(46.7 \%)$ & & & & \\
\hline \multicolumn{7}{|c|}{ Pulmonary Tb Co-infection } \\
\hline Yes & $48(45.7 \%)$ & $22(21 \%)$ & & & 3.177 & 0.000 \\
\hline No & $57(54.3 \%)$ & $83(79 \%)$ & & & & \\
\hline \multicolumn{7}{|c|}{ Hepatitis B Co-infection } \\
\hline Yes & $11(16.9 \%)$ & $5(7.4 \%)$ & & & 2.567 & 0.153 \\
\hline No & $54(83.1 \%)$ & $63(92.6 \%)$ & & & & \\
\hline \multicolumn{7}{|c|}{ Hepatitis C Co-infection } \\
\hline Yes & $5(10.6 \%)$ & $2(4.7 \%)$ & & & 2.440 & 0.506 \\
\hline No & $42(89.4 \%)$ & $41(95.3 \%)$ & & & & \\
\hline \multicolumn{3}{|c|}{ CD4 Count $\left(\right.$ cell $\left./ \mathrm{mm}^{3}\right)$} & & 103.73 & & \\
\hline$<200$ & $82(95.3 \%)$ & $69(66.3 \%)$ & & & 10.399 & 0.000 \\
\hline$\geq 200$ & $4(4.7 \%)$ & $35(33.7 \%)$ & & & & \\
\hline \multicolumn{2}{|c|}{ eGFR (mL/minute/1.72 $\left.\mathrm{m}^{2}\right)$} & & & 80.42 & & \\
\hline$<60$ & $43(41 \%)$ & $19(18.1 \%)$ & & & 3.139 & 0.001 \\
\hline$\geq 60$ & $62(59 \%)$ & $86(81.9 \%)$ & & & & \\
\hline Hb Level (g/dL) & & & & 11.0 & & \\
\hline$<10$ & $44(41.9 \%)$ & $25(23.8 \%)$ & & & 2.308 & 0.008 \\
\hline$\geq 10$ & $61(58.1 \%)$ & $80(76.2 \%)$ & & & & \\
\hline
\end{tabular}

*Chi-square test

Multivariate analysis using logistic regression test. Based on the results of the chi-square test, variables having $\mathrm{p}<0.05$ were included in the multivariate analysis. These variables include male ( $p$ $=0.030)$, age $\geq 45$ years $(p=0.035)$, non-compliance with treatment $(p=0.000)$, WHO III and IV clinical stages $(p=0.000)$, pulmonary tuberculosis coinfection $(p=0,000)$, CD4 count $<200$ cells $/ \mathrm{mm}^{3}(p$ $=0,000)$, eGFR $<60 \mathrm{~mL} /$ minute $/ 1.72 \mathrm{~m}^{2}(p=0.001)$
$=0.08)$. After multivariate analysis, 2 variables showed $\mathrm{p}$ value $<0.05$, namely non-compliance to treatment $(p=0.003)$ and CD4 count $<200$ cells $/ \mathrm{mm}^{3}$ ( $p=0.014)$, which are the most significant risk factors for mortality in HIV/AIDS patients at Dr. Kariadi General Hospital Semarang. The complete data is described in Table 2. 
Table 2. Multivariate Analysis of Risk Factors for Mortality in HIV/AIDS Patients

\begin{tabular}{|c|c|c|c|}
\hline No & Variable & OR & $p$ \\
\hline 1 & Male & 2.074 & 0.105 \\
\hline 2 & Age $\geq 45$ years & 1.347 & 0.531 \\
\hline 3 & $\begin{array}{l}\text { Non-compliance to } \\
\text { treatment }\end{array}$ & 3.285 & 0.003 \\
\hline 4 & $\begin{array}{l}\text { WHO III and IV } \\
\text { clinical stages }\end{array}$ & 1.085 & 0.997 \\
\hline 5 & $\begin{array}{l}\text { Pulmonary } \\
\text { Tuberculosis co- } \\
\text { infection }\end{array}$ & 1.085 & 0.834 \\
\hline 6 & $\begin{array}{l}\text { CD4 count }<200 \\
\text { cell } / \mathrm{mm}^{3}\end{array}$ & 5.480 & 0.014 \\
\hline 7 & $\begin{array}{l}\text { eGFR }<60 \\
\mathrm{~mL} / \text { minute } / 1.72 \mathrm{~m}^{2}\end{array}$ & 1.949 & 0.126 \\
\hline 8 & $\begin{array}{l}\mathrm{Hb} \text { level }<10 \mathrm{~g} / \mathrm{dL} \\
\text { Constant }\end{array}$ & $\begin{array}{l}1.625 \\
0.000\end{array}$ & $\begin{array}{l}0.270 \\
0.996\end{array}$ \\
\hline
\end{tabular}

\section{Discussion}

The number of HIV/AIDS patients in this study was based on gender according to data from the Directorate General of Disease Prevention and Control of the Ministry of Health of the Republic of Indonesia in 2017 which stated that there were more males than females based on data from 1987-2017, namely men amounting to $56.5 \%$, female $31.6 \%$ while $11.8 \%$ did not report gender. This is related to sexual intercourse (heterosexual) which is the main transmission of HIV transmission, where transmission through heterosexual intercourse is more common in the male sex. ${ }^{3}$ Male is a risk factor for mortality in HIV/AIDS patients with a risk of death 1.966 times greater than that of women ( $p$ $=0.030$, OR 1.966). This is in accordance with the research of Gunda W, et al in 2017 which stated that male is a risk factor for the mortality of HIV/AIDS patients. ${ }^{7}$ Biological differences between gender, such as the effect of sex hormones on immunity, greatly influence the progression of HIV infection. The immune system of men and women is the same before the reproductive period, but begins to differ when they enter reproductive age. Female when they enter the reproductive period are more immune to infection. This is caused by the production of the female hormone estrogen which affects the increased synthesis of $\operatorname{IgG}$ and $\operatorname{IgA}$. 17 3 -estradiol (E2) which is the main and most potent estrogen in female works by binding to estrogen receptors (ER) in the reproductive tract tissue and in immune cells in peripheral blood, including CD4 $\mathrm{T}$ cells and macrophages which are 2 target cells primary HIV so E2 has antiviral properties against HIV. E2 acts directly on CD4 T cells and macrophages to inhibit HIV replication. ${ }^{8,9,10}$
The number of HIV/AIDS patients based on age in this study is according to data from the Directorate General of Disease Prevention and Control of the Ministry of Health of the Republic of Indonesia in 2017 which states that most occur in the age group of $20-29$ years $(31.4 \%)$ followed by $30-39$ years ( $30.6 \%)$ and $40-49$ years old $(12.8 \%) .{ }^{3}$ Age $<45$ years is the group most infected with HIV because it is associated with active sex, which is the main transmission of HIV transmission. ${ }^{11}$ Age $\geq 45$ years is a significant risk factor for mortality in HIV/AIDS patients with a risk of 2.119 times greater than those aged $<45$ years $(p=0.035$, OR 2.119). This is in accordance with the research of Rubaihayo, et al in 2015 which stated that age $\geq 45$ years is a strong risk factor for the mortality of HIV/AIDS patients. ${ }^{12}$ Zheng, et al in 2014 stated that if the age> 45 years have a greater risk of mortality than those aged 18-29 years. ${ }^{13}$ The age limit of $<45$ years and $\geq 45$ years is based on the fact that at $\geq 45$ years of age there is a thymus involution where the thymus volume is significantly smaller compared to young age. The thymus is an important organ in the development of the immune system and has a primary function as a site for T lymphocyte maturation. ${ }^{14}$ Increasing age is associated with decreased immune and physiological function. The immune system matures in adulthood and declines again at old age. ${ }^{11}$ Older age is a strong risk factor in accelerating the progression of HIV infection and increasing AIDS-related mortality. ${ }^{15}$

Non-compliance to treatment was one of the most important risk factors for mortality in HIV/AIDS patients in this study. Research subjects died more in research subjects who were noncompliance to treatment. Non-compliance to treatment was a risk factor for mortality in HIV/AIDS patients and had a risk of 5.805 times greater than that of patients who were compliance to treatment ( $p$ $=0.000$, OR 5.805) and in multivariate analysis was the most important risk factor for the mortality of HIV/AIDS patients $(p=0.003)$. This is consistent with a study by Stringer, et al in 2008 which stated that non-compliance was a risk factor for mortality during the use of ARV. ${ }^{16}$ Research by Ayalew, et al in 2017 states that non-compliance to taking ARV is a risk factor for mortality in HIV/AIDS patients where non-compliance to ARV causes treatment failure with an increase in the occurrence of mutations that can lead to HIV resistance to ARV and eventually lead to death. ${ }^{17}$ Non-compliance to treatment is an important factor for treatment failure in HIV/AIDS patients where there is a significant relationship between non-compliance to taking medication with failure of HIV suppression, increased HIV resistance, decreased CD4 cell counts 
and decreased expectations and quality of life. ${ }^{18}$ WHO clinical stages III and IV are risk factors for mortality of HIV/AIDS patients in this study. This is in accordance with research by Gunda W, et al in 2017 and by Utami, et al in 2015 which stated that the WHO clinical stages III and IV were risk factors for the mortality of HIV/AIDS patients. ${ }^{71}$ Clinical stages III and IV have a more severe clinical picture than clinical stages I and II. ${ }^{6}$ The clinical stage of HIV/AIDS is strongly influenced by the CD4 count. CD4 count $<200$ cells $/ \mathrm{mm}^{3}$ will increase the risk for opportunistic infections. The lower CD4 cell count, the more and more opportunistic infections will occur, causing the clinical stage of HIV/AIDS to become increasingly severe. ${ }^{20}$ HIV/AIDS clinical stage, treatment compliance and CD4 count are variables that are strongly interrelated and cannot be separated. Non-compliance to ARV will reduce CD4 counts, which in turn can lead to opportunistic infections, which will aggravate the clinical stage of HIV/AIDS and increase mortality.

Pulmonary tuberculosis co-infection was a risk factor for the mortality of HIV/AIDS patients in this study and someone with pulmonary tuberculosis coinfection had a 3.177 times greater risk of mortality than someone without pulmonary tuberculosis coinfection ( $p=0.000$, OR 3.177). This is consistent with research by Rajagopalan N, et al in 2009 and by Hamidi O, et al in 2017 which stated that pulmonary tuberculosis co-infection is a risk factor for mortality in HIV/AIDS patients. ${ }^{21,22}$ Pulmonary tuberculosis is the most common cause of death for HIV/AIDS patients. The risk of death for HIV-infected persons with pulmonary tuberculosis co-infection is twice that of those without pulmonary tuberculosis coinfection. ${ }^{23}$ Patients with pulmonary tuberculosis coinfection are included in clinical stage III so that the relationship between pulmonary tuberculosis coinfection, clinical stage III, non-compliance to treatment and CD4 count $<200$ cells $/ \mathrm{mm}^{3}$ are closely related. Research by Kumar, et al in 2017 stated that a mean CD4 count of 74.5 cells $/ \mathrm{mm}^{3}$ would increase the risk of pulmonary tuberculosis co-infection in someone with HIV infection. ${ }^{24} \mathrm{CD} 4$ is the best parameter for measuring immunodeficiency. CD4 count $<200$ cells $/ \mathrm{mm}^{3}$ in this study was a risk factor for mortality in HIV/AIDS patients with a risk of 10.399 times greater than a CD4 count $\geq 200$ cells $/ \mathrm{mm}^{3} \quad(p=0.000$ OR 10.399) and in the multivariate analysis was the most important risk factor for mortality in HIV/AIDS patients $(p=0.014)$. This is consistent with research by Gunda W, et al in 2017, Chen L, et al in 2017 and Garriga C, et al in 2015 which stated that CD4 $<200$ cells $/ \mathrm{mm}^{3}$ was a risk factor for mortality in HIV/AIDS patients. ${ }^{26,7,27}$
CD4 count is closely related to treatment compliance. This can be seen in the results of this study, where the 2 variables that played the most role as risk factors for mortality in HIV/AIDS patients were noncompliance to treatment and CD4 count $<200$ cells $/ \mathrm{mm}^{3}$. Non-compliance to ARV results in lower CD4 cell counts whereas ARV therapy has been shown to reduce viral load, increase CD4 cell count, improve quality of life, reduce opportunistic infections and thus reduce morbidity and mortality. ${ }^{25}$ CD4 cell count is an important prognostic indicator of remaining levels of immune function. ${ }^{28} \mathrm{CD} 4$ cells are an early indication of disease progression because CD4 counts have decreased before clinical conditions. ${ }^{25} \mathrm{CD} 4$ count is the single best laboratory parameter for determining the clinical outcome of HIV/AIDS patients. CD4 count strongly predicted HIV infection progression, risk of opportunistic infections and short-term death. Lower CD4 counts correlate with an increased risk of morbidity and mortality in HIV/AIDS patients. CD4 count <200 cells $/ \mathrm{mm}^{3}$ was defined as the lower threshold for severe opportunistic infections in general. ${ }^{28}$

eGFR $<60 \mathrm{~mL} /$ minute $/ 1.72 \mathrm{~m}^{2}$ in this study was a risk factor for mortality in HIV/AIDS patients with a risk of 3.139 times greater than eGFR $\geq 60$ $\mathrm{mL} /$ minute $/ 1.72 \mathrm{~m}^{2}$ ( $p=0.001$, OR 3.139). This is consistent with research by Kim J, et al in 2017 which stated that eGFR $<60 \mathrm{~mL} /$ minute $/ 1.72 \mathrm{~m}^{2}$ is a risk factor for mortality in HIV/AIDS patients. ${ }^{29}$ eGFR of someone infected with HIV is an accurate marker that is useful in diagnosing HIVAN and other glomerular diseases early and identify patients at high risk for rapid kidney function decline which will lead to an increased risk of cardiovascular disease. Kidney disease remains a significant cause of morbidity and mortality. Kidney disease is known as a complication of HIV and has an important role in the mortality of HIV/AIDS patients. ${ }^{30}$ Anemia is the most common hematological disorder in HIV/AIDS patients in Indonesia and is associated with HIV disease progression and poor clinical outcomes. ${ }^{31}$ Hemoglobin level $<10 \mathrm{~g} / \mathrm{dL}$ was a risk factor for mortality in HIV/AIDS patients in this study and had a risk of 2.308 times greater than $\mathrm{Hb}$ levels $\geq 10 \mathrm{~g} / \mathrm{dL}$ ( $p=0.008$, OR 2.308). This is in accordance with research by Damtew et al in 2015 which stated that Hemoglobin $<10 \mathrm{~g} / \mathrm{dL}$ was a risk factor for mortality in HIV/AIDS patients. ${ }^{32}$ Hemoglobin level reflects the speed of disease progression and can predict the prognosis of a disease. A decrease in $\mathrm{Hb}$ levels correlates with a decrease in CD4 counts, so in this study there is a close relationship between $\mathrm{Hb}$ levels and CD4 counts. ${ }^{33} \mathrm{CD} 4$ count $<200$ cells $/ \mathrm{mm}^{3}$ and non-compliance to treatment as previously 
mentioned were the most significant risk factors for mortality in HIV/AIDS patients in this study so that someone who was not compliance to treatment would cause a decrease in CD4 counts which eventually led to a decrease in $\mathrm{Hb}$ levels. Some opinions state that an increase in $\mathrm{Hb}$ levels can predict the success of therapy so that someone who is compliance to treatment will increase the CD4 count and $\mathrm{Hb}$ level which ultimately leads to success of therapy and reduces mortality. Anemia is associated with the progression of AIDS and with shorter survival of HIV/AIDS patients. Anemia in HIV/AIDS is a marker of progression of HIV disease because it is one of the clinical features of most opportunistic infections. This occurs due to micronutrient deficiency and impaired erythropoietin production. In addition, various drugs used by HIV patients also play a role in the onset of anemia, for example Zidovudine. Anemia causes hypoxia in which the blood's ability to bind oxygen is reduced due to the reduced number of hemoglobin molecules. Anemia in severe infection causes tissue hypoxia which can progress to multi-organ failure leading to mortality. ${ }^{33}$

The level of education in this study is divided into the level of basic education (no school, elementary, junior high school) and advanced education level (senior high school and college). Most of the patients who died were patients with advanced education level of 76 people $(72.4 \%)$ while 29 people $(27.6 \%)$ had a basic education level with a $\mathrm{p}$ value of 0.650 so that the level of primary education was not a risk factor for mortality in HIV/AIDS patients. This is consistent with research by Bhatta, et al in 2013 and research by Okonkwo, et al in 2014 which did not have a relationship between the level of primary education and mortality. ${ }^{34}$ The absence of a relationship between education level and mortality in this study can be attributed to the condition that most $(70.5 \%)$ of the sample of this study were dominated by advanced education levels (senior high school and college). This can occur because individuals with low basic education have low awareness of access to health services and medical care so they do not seek health services if they are sick. ${ }^{35}$

HIV-Hepatitis B co-infection has a high prevalence. The relationship of Hepatitis B coinfection with HIV/AIDS patient mortality is still controversial. ${ }^{36}$ All people living with HIV must undergo routine $\mathrm{HBsAg}$ examinations to detect early hepatitis B co-infection. Based on the data of this study, not all HIV/AIDS patients in Dr. Kariadi General Hospital Semarang routinely performed Hepatitis B screening tests. Hepatitis B screening examinations were only performed on 133 patients
$(63.33 \%)$. Based on these data, only 11 patients $(10.47 \%)$ with hepatitis B co-infection died while 54 patients $(51.42 \%)$ died without hepatitis B coinfection. The results of this study were that hepatitis B co-infection was not a risk factor for HIV/AIDS patient mortality ( $p=0.153$ ). This is consistent with research by Knapp, et al in 2013 which stated that there was no difference in life expectancy between HIV/AIDS positive and negative HBsAg patients and research by Rockstroh in 2006 which stated that Hepatitis B co-infection was not a risk factor for mortality in HIV/AIDS patients..$^{37,38}$ Research from the Multicenter AIDS Cohort Study (MACS) also states that there is no relationship between Hepatitis B co-infection and the mortality of HIV/AIDS patients. ${ }^{37}$ Some of the reasons why Hepatitis B coinfection was not a risk factor for the mortality of HIV/AIDS patients in this study were that there were still many HIV/AIDS patients who had not undergone routine HBsAg examinations, namely 77 people $(36.66 \%)$. Another thing is that all the subjects of this study have received ARV HIV/AIDS therapy where this ARV therapy reduces the progression of liver disease in HIV/AIDS patients with Hepatitis B co-infection, thereby reducing mortality. ${ }^{25}$ The mortality risk of HIV patients with hepatitis B coinfection is 3 times greater than that of HIV patients without hepatitis B co-infection and occurs when the hepatitis B infection has caused liver cirrhosis or complications of portal hypertension have occurred. Cirrhosis of the liver and its complications is a strong risk factor for mortality in HIV patients co-infected with Hepatitis B. ${ }^{39}$

Patients infected with HIV/AIDS should be screened for Hepatitis $\mathrm{C}$ virus infection. Initial screening for Hepatitis $\mathrm{C}$ is carried out with anti$\mathrm{HCV}$ testing. ${ }^{40} \mathrm{Co}$-infection of HIV with Hepatitis C can affect the natural course of the Hepatitis $C$ virus. Hepatitis $\mathrm{C}$ screening tests should be carried out routinely in all HIV/AIDS patients, especially in preparation for ARV administration. ${ }^{25}$ Based on this research data, there are still many HIV/AIDS patients in Dr. Kariadi General Hospital who has not been routinely tested for Anti HCV. Only 90 patients $(42.85 \%)$ were tested for Anti HCV. Based on this number, 5 patients $(4.76 \%)$ died with Hepatitis $\mathrm{C}$ coinfection while 42 patients $(40 \%)$ died without Hepatitis $\mathrm{C}$ co-infection. The results of this study indicate that Hepatitis $\mathrm{C}$ co-infection is not a risk factor for mortality in HIV/AIDS patients ( $\mathrm{p}$. = 0.506). This is consistent with a study by Rockstroh in 2006 which stated that Hepatitis C co-infection is not a risk factor for the mortality of HIV/AIDS patients. ${ }^{38}$ Several reasons that Hepatitis $\mathrm{C}$ coinfection was not a risk factor for the mortality of 
HIV/AIDS patients in this study were that there were still many samples of the study that had not been subjected to routine anti-HCV examinations, namely 120 people $(57.14 \%)$. The provision of ARV for HIV/AIDS patients was also related to this, where all research subjects in this study had received ARV HIV/AIDS therapy. Administration of ARVs in HIV/AIDS patients with Hepatitis C co-infection will slow the progression of liver fibrosis, reduce liver inflammation and reduce the risk of liver-related death in Hepatitis C co-infected patients. ${ }^{40}$ Immune restorations with ARV therapy has an important effect in reducing the risk of mortality in patients coinfected with Hepatitis C. Therefore, HIV/AIDS patients coinfected with Hepatitis $\mathrm{C}$ are recommended to be given ARV earlier than HIV/AIDS patients without Hepatitis C coinfection. ${ }^{41}$

Multivariate analysis showed that the most significant risk factors for mortality in HIV/AIDS patients were non-compliance to treatment and a CD4 count $<200$ cells $/ \mathrm{mm}^{3}$. This is consistent with research by Ayalew, et al in 2017 which stated that the risk factors for mortality that most played a role in HIV/AIDS patients were non-compliance with treatment and low CD4 counts. ${ }^{17}$ The two risk factors for mortality have a strong relationship. Noncompliance to ARV therapy results in lower CD4 counts where ARV therapy has been shown to reduce viral load counts, increase CD4 cell counts, improve quality of life, reduce opportunistic infections and thus reduce morbidity and mortality. ${ }^{25}$ Noncompliance to treatment in this case was defined as taking ARV $<95 \%$ of the dose within a month. Noncompliance to treatment and CD4 count $<200$ cells $/ \mathrm{mm}^{3}$ also had an effect on other significant mortality risk factors, including male gender, age $\geq$ 45 years, WHO III and IV clinical stages, pulmonary tuberculosis co-infection, eGFR $<60 \mathrm{~mL} /$ minute $/ 1.73$ $\mathrm{m}^{2}$ and $\mathrm{Hb}$ content $<10 \mathrm{~g} / \mathrm{dL}$. Non-compliance to treatment was more common in the male sex, which would cause a low CD4 count. Older age, in this case age $\geq 45$ years, is a risk factor for treatment noncompliance which ultimately leads to a lower CD4 count. Non-compliance to treatment and CD4 count $<200$ cells $/ \mathrm{mm}^{3}$ had a strong association with WHO III and IV clinical stages. CD 4 count $<200$ cells $/ \mathrm{mm}^{3}$ is a risk factor for the emergence of opportunistic infections and co-infection at the WHO III and IV clinical stages. The lower the CD4 count, the heavier and more opportunistic infections and co-infections will occur. One of the co-infections that are often found at WHO clinical stage III is pulmonary tuberculosis. An average CD4 count of 74.5 cells $/ \mathrm{mm}^{3}$ will increase the risk of pulmonary tuberculosis co-infection in HIV/AIDS patient. ${ }^{24}$

eGFR $<60 \mathrm{~mL} /$ minute $/ 1.73 \mathrm{~m}^{2}$ is a risk factor for increased cardiovascular events in HIV/AIDS patients which will increase the risk of mortality. This is associated with a low CD4 count. A low CD4 count increases the risk of developing renal insufficiency. ${ }^{29}$ A decrease in $\mathrm{Hb}$ levels correlates with a decrease in CD4 counts so that non-compliance to treatment will lead to a decrease in CD4 counts which will eventually lead to a decrease in $\mathrm{Hb}$ levels. ${ }^{33}$

\section{Conclusion}

Risk factors for mortality in HIV/AIDS patients include male gender, age $\geq 45$ years, non-compliance to treatment, WHO III and IV clinical stages, pulmonary tuberculosis co-infection, CD4 count $<200$ cells $/ \mathrm{mm}^{3}$, eGFR $<60 \mathrm{~mL} /$ minute $/ 1,72 \mathrm{~m}^{2}$ and $\mathrm{Hb}$ content $<10 \mathrm{~g} / \mathrm{dL}$. The risk factors for mortality that played the most role were non-compliance to treatment and a CD4 count $<200$ cells $/ \mathrm{mm}^{3}$.

\section{Ethical Approval}

Ethical clearance has been approval by Health Research Ethics Committee Faculty of Medicine Diponegoro University and Dr Kariadi General Hospital. The number of ethical clearance is 411/EC/FK-RSDK/VI/2018

\section{References}

1. Hamidi O, Poorolajal J, Tapak L. Identifying predictors of progression to AIDS and mortality post-HIV infection using parametric multistate model. Journal of Epidemiology Biostatistics and Public Health 2017; 14(2): 34-40.

2. Kementerian Kesehatan RI. Situasi dan Analisis HIV/AIDS. Jakarta: Infodatin; 2016; 18.

3. Direktorat Jenderal Pencegahan dan Pengendalian Penyakit Kementerian Kesehatan Republik Indonesia. Laporan Perkembangan HIV-AIDS \& Penyakit Infeksi Menular Seksual Triwulan I Tahun 2017: 4.

4. Sumantri R, Supandiman I, Indjradinata P, Ven D, Crevel V. Peluang Kematian Penderita Human Immunodeficiency Virus - Acquired Immune Deficiency Syndrome berdasarkan Gabungan Derajat Anemia, Indeks Massa Tubuh, dan Jumlah Cluster Differentiation 4. Jurnal FK Unpad 2012; 44(1): 50-6.

5. Walubita L. The Predictive Value of Anaemia in Determining Mortality in Patients with HIV at The University Teaching Hospital, Lusaka, Zambia. A Dissertation. 2016: 6. 
6. Utami S. Prediktor Kematian Pasien HIV/AIDS dengan Terapi Antiretroviral (ARV) di Rumah Sakit Umum Daerah Badung Bali Periode 20062014. Tesis.2015: 34.

7. Gunda W, Nkandala I, Kilonzo B, Kilangi B, Mpondo C. Prevalence and Risk Factors of Mortality among Adult HIV Patients Initiating ART in Rural Setting of HIV Care and Treatment Services in North Western Tanzania: A Retrospective Cohort Study. Journal of Sexually Transmitted Diseases 2017; 4(2): 1-8.

8. Maskew M, Brennan $\mathrm{T}$, Westreich D, McNamara L. Gender Differences in Mortality and CD4 Count Response Among Virally Supressed HIV-Positive Patients. Journal of Women's Health 2013; 22(2): 113-20.

9. Szotek L, Narasipura D, Harthi A. 17- $\beta$ Estradiol Inhibits HIV-1 by Inducing a Complex Formation Between $\beta$-Catenin and Estrogen Receptor on The HIV Promoter to Suppress HIV Transcription. Journal of Virology 2013; 443(2): 1-21.

10. Garcia R, Biswas N, Patel V, Barr D, Crist G, Ochsenbauer, et al. Estradiol Reduces Susceptibility of CD4 T Cells and Macrophages to HIV-Infection. 2013. [cited 2017 December 21]. Available from: http//www.plosone.org.

11. Sharrow J, Collinson A, Tollman M, Clark J, Kahn K. The Age Pattern of Increases in Mortality Affected by HIV 2013; 2(39): 103996.

12. Rubaihayo J, Tumwesigye M, Lule K, Makumbi F, Nakku J, Wamani H, et al. Trends and Risk Factors of Mortality Among HIV Positive Patients in The Era of Highly Active Antiretroviral Therapy in Uganda. Infectious Disease Reports 2015; 7: 5967.

13. Zheng L, Taiwo B, Gandhi T, Hunt W, Collier $\mathrm{C}$, Flexner $\mathrm{C}$, et al. Factors Associated with CD8+ T-Cell Activation in HIV-1-Infected Patients on Long-Term Antiretroviral Therapy. Journal Acquired Immune Deficiency Syndrome 2014; 67: 153-60.

14. Nguyen N, Holodny M. HIV Infection in The Elderly. Clinical Intervention in Aging 2008; 3(3): 453-72.

15. Clark J, Thomas L. Age-Related Immune Dysfunction in Health and in Human Immunodeficiency Virus (HIV) Disease: Association of Age and HIV Infection with Naive CD8+ Cell Depletion, Reduced Expression of CD28 on CD8+ Cells, and Reduced Thymic Volumes. The Journal of Infectious Disease 2013; 187(12): 1924-33.
16. Stringer J, Zulu I, Levy J, Stringer E, Mwango A, Chi H, et al. Rapid Scale-up of Antiretroviral Therapy at Primary Care Sites in Zambia. The Journal of the American Medical Association 2008; 296(7): 782-93.

17. Ayalew B. Risk Factors for Mortality and Its Predictors among HIV Infected Patients Taking Antiretroviral Treatment in Ethiopia: A Systematic Review. AIDS Research and Treatment 2017; 1-10.

18. Kenneth L. The Importance of Treatment Compliance in HIV. The American Journal of Managed Care 2013; 19: 231-37.

19. Utami S, Sawitri A, Putra E, Astuti P, Januraga $\mathrm{P}$, Wulandari L, et al. Mortality Among HIV Patients on Antiretroviral Treatment (ART) in Bali, Indonesia 2006-2014. The Australian HIV \& AIDS Conference 2015. Brisbane.

20. Mala E, Oberoi A. Opportunistic Infections in Relation to CD4 Counts in Human Immunodeficiency Virus Seropositive Patients in A Tertiary Care Hospital in North India. Journal of Health and Research 2015; 2: 199 202.

21. Rajagopalan N, Suchitra B, Shet A, Khan K, Garcia M, Nonnemacher R, et al. Mortality Among HIV-Infected Patients in Resource Limited Settings: A Case Controlled Analysis of Inpatients at A Community Care Center. American Journal Infectious Disease 2009; 5(3): $1-10$.

22. Hamidi O, Tapak L, Poorolajal J, Amini P. Identifying Risk Factors for Progression to AIDS and Mortality Post-HIV Infection Using Illness-Death Multistate Model. Journal of Clinical Epidemiology and Global Health. 2017: 163-68; Available from: http://www.elsevier.com

23. Gjergji M, Bushati J, Harxhi J, Hafizi H, Pipero P. Tuberculosis in HIV/AIDS Patients. Journal of Epidemiology and Infectious Diseases 2017; 1: 1-7.

24. Kumar A, Kalakappa P. Spectrum of Opportunistic Infections with Correlation to CD4 Counts in Newly Diagnosed HIV Seropositive Cases. International Journal of Advances in Medicine 2017; 4(1): 252-58.

25. Peraturan Menteri Kesehatan Republik Indonesia Nomor 87 Tahun 2014. Pedoman Pengobatan Antiretroviral; 9-25.

26. Garriga C, Garcia P, Miro J. Mortality, Causes of Death and Associated Factors Relate to a Large HIV Population -Based Cohort. 2015. [cited 2017 December 25]. Available from: www.journal.pone.0145701. 
27. Chen L, Pan X, Jiang J. HIV Cause-Specific Deaths, Mortality, Risk Factors, and The Combined Influence of HAART and Late Diagnosis in Zhejiang, China, 2006-2013. Scientific Report 2017;7(42366):1-18.

28. Ray W, Anthony K. Low CD4 Count as an Indicator of Disability. National Academy of Sciences 2017: 45-47.

29. Kim J, Ahn Y. The Prevalence and Risk Factors of Renal Insufficiency among Korean HIVInfected Patients: The Korea HIV/AIDS Cohort Study. Journal of Infection and Chemotherapy 2017; 49(3): 194-204.

30. Longenecker T, Scherzer R, Bacchetti R, Lewis E, Grunfeld C, Shlipak C. HIV Viremia and Changes in Kidney Function. AIDS 2009; 23(9): 1089-96.

31. Redig J, Berliner N. Pathogenesis and Clinical Implications of HIV -Related Anemia in 2013. Journal of American Society of Haematology 2013; 5(31): 377-82.

32. Damtew B, Mengistie B, Alemayehu T. Survival and Determinants of Mortality in Adult HIV/AIDS Patients Initiating Antiretroviral Therapy in Somali Region, Eastern Ethiopia. Pan African Medical Journal 2015; 22(138): 18.

33. Obirikorang C, Yeboah F. Blood Haemoglobin Measurements as A Predictive Indicator for The Progression of HIV/AIDS in Resource Limited Setting. Journal of Biomedical Science 2009; 16(102): 1-7.

34. Bhatta L, Klouman E, Deuba K, Shrestha R, Kumar D, Mia A, et al. Survival on
Antiretroviral Treatment Among Adult HIVInfected Patients in Nepal: A Retrospective Cohort Study in Far-Western Region, 20062011. BMC Infectious Diseases 2013; 13(604): 1-9.

35. Mahon J, Wanke C, Terrin N, Skinner S, Knox T. Poverty, Hunger, Education, and Residential Status Impact Survival in HIV. AIDS Behaviour 2011; 15(7): 1503-11.

36. World Health Organization. HIV Treatment and Care: What's New in Treatment Monitoring Viral Load and CD4 Testing. Geneva: WHO Press; 2017; 1-2.

37. Knapp O, Cortes P, Saavedra F, Wolff M, Weitzel T. Hepatitis B Prevalence and Influence on HIV Treatment Outcome and Mortality in the Chilean AIDS Cohort. International Journal of Infectious Diseases 2013; 17: 919-24.

38. Rockstroh K. Influence of Viral Hepatitis on HIV Infection. Journal of Hepatology 2006; 44(2006): 25-7.

39. Rajbhandari R, Jun $\mathrm{T}$, Khalili $\mathrm{H}$, Chung $\mathrm{T}$, Ananthakrishnan N. HBV/HIV Co-infection is Associated with Poorer Outcomes in Hospitalized Patients with HBV or HIV. Journal Viral Hepatology 2016; 23(10): 820-9.

40. Clausen N, Lundbo F, Benfield T. Hepatitis C Virus Infection in The Human Immunodeficiency Virus Infected Patient. World Journal Gastroenterology 2014; 20(34): 12132-43.

41. National AIDS Trust (NAT). Hepatitis C and HIV Co-infection. England: New City Cloisters; 2012; 1-14. 